\title{
Integrated Movable System of Fuel Cell with Replaceable Fiber Bipolar Plate
}

\author{
Chang Shiuh Ming ${ }^{1 *}$, Kuo Jenn Kun ${ }^{2}$ \\ ${ }^{1}$ Department of Mechanical and Automation Engineering, Kao Yuan University, Kaohsiung, Chinese Taipei; ${ }^{2}$ Institute of Greenergy \\ National, University of Tainan, Taiwan, Chinese Taipei. \\ Email: ${ }^{*}$ csmoo@cc.kyu.edu.tw
}

Received May $27^{\text {th }}$, 2011; revised June $17^{\text {th }}$, 2011; accepted July 24 $4^{\text {th }}, 2011$.

\begin{abstract}
It is important for the fuel cell integrated movable system to operate voltage and current using safety control technology. In order to work at the convenient condition of the fuel cell system, high performance fuel cell stack with replaceable fiber bipolar plate should be arranged with the integrated subsystem and appropriate working process. The parameters which affect the performance of PEMFC consisting of relative humidity, reaction temperature, gas inlet temperature, gas inlet pressure, and hydrogen and air flow rate. This study is to develop the integrated movable system on distributed power generation and backup power application, such as oxidant supply system, fuel supply system, heat management system, water management system, and power conditioning system. It comprises a novel PLC (Programmable Logic Control) system and human-machine interface. The controller is developed to control fuel cell system and record the operation data by using data acquisition system. The controller can be applied to high performance stack and system to obtain the best performance. The easy-taken high capacity hydrogen barrel embedded into steel plate of this movable system and more convenient than other fuel cell system.
\end{abstract}

Keywords: Movable System, Fiber Bipolar Plate, PEMFC, PLC, Control System, Touch Panel, Easy-Taken

\section{Introduction}

Many researchers have discussed the importance and the need for well designed control system for fuel cell power supply. From the discussions with control engineers and researchers in the area of fuel cell technology, it became apparent that a comprehensive development with a control-oriented approach to modeling, analysis, design, and cost down was needed. To replace conventional power sources, fuel cell systems must exhibit exceptional performance, efficiency and reliability. Important properties that affect the performance of PEM fuel cells include transport of reactants and byproducts, rejection of the heat generated by electrochemical reactions or by the current passing through the fuel cell and control of fuel cell stack, hydrogen fueling, reaction temperature, air supply, cooling, PLC controller, power conversion, and data acquisition to maintain adequate electrolyte conductivity [1].

Fuel cell systems offer clear and efficient energy production and are currently under intensive development by several manufactures for both stationary and mobile applications. The viability, efficiency, and robustness of the fuel cell technology depend on understanding, predicting, monitoring, and controlling the fuel cell system under a variety of environmental conditions and wide operating range. The system is not optimized in weight and dimension; it is only a first low-cost prototype, useful to demonstrate the technology of fuel cells on stationary power sources to obtain direct information on operating tests.

The development of new fuel cell control system and the application to household appliances or standby power, such as the hydrogen supply system, air supply systems, cooling and heat recycle loop, cooling circulation system, power conversion system, and advanced intelligent control systems, fuel cell power generation system can be operated under the best conditions, while the development of fuel cell controller and the control method and measured fuel cell data can facilitate the search for the best fuel cell design and operating conditions, and finally provide high-efficiency and high power density. The proton exchange membrane fuel cell group is required by the conditions of the target

\section{Movable PEM Fuel Cell Control System}

The intelligent movable PEM fuel cell with replaceable 
fiber bipolar plate control system is the center of the fuel cell system, and the success in integrating a fuel cell system relies on the proper operation of each component in the system, as shown on Figure 1 (Functional block diagram of the fuel cell control system). The major components of fuel cell system includes a high pressure gaseous hydrogen cylinder, an air compressor, a humidifier, solenoid valves, pressure regulators, sensors (for temperature, pressure, voltage, and current), cooling fan, converter, inverter, touch panel, PLC controller, pipes, and fittings. They are grouped into subsystems by PLC controller and will be discussed in detail in the following. The design and construction of these subsystems are based on the PEM fuel cell operating conditions listed in Table 1. It is noted that fuel cells become contaminated, such as air compressor supply subsystem, air fan cooling subsystem, hydrogen fueling system, and PLC controller system. Such requirements means that many of the components have to be carefully selected, custom-built, ordered form laboratory supply companies, and friendlier human-machine interface.

\subsection{Fuel Cell}

Several PEM fuel cell models are reported in the literatures [2-9] base on the thermodynamic and electrochemical equations. In most of the cases, the dynamic behavior of the fuel cell stacks is analyzed for constant hydrogen pressure operation only for simplicity. The effect of changes in inlet fuel pressures and operating tempera- tures of PEM fuel cell models are also addressed [2]. It has been observed that the fuel cell can be operated dramatically within the linear region by changing the internal resistance offered by the fuel cell stack with different loading conditions under different hydrogen pressure operations. Real et al. [4] proposed a semi-empirical formulation of fuel cell model based on theoretical and experimental results.

The fuel cell stack not only provides the propulsion for the stationary electric supply but also powers the components of all subsystems, like the water pump. The fuel cell stack can be operated under a wide range of voltages $(30-48 \mathrm{~V})$. Thus, it is directly powered by the fuel cell stack of a range dynamic voltage. The electric power supplied to the supported components from the fuel cell stack should be regulated in voltages using $\mathrm{dc} / \mathrm{dc}$ converters

The air supply subsystem provides the fuel cell stack with clean air of $\mathrm{RH}>80 \%$ (relative humidity). As shown in Figure 1, the ambient air is drawn into the oxidant feeding line and through a particular-designed filter by using a fan-blower to keep it away from dusts or particle. A load-following technique is employed in the design of the oxidant supply subsystem, that is, the blower varies its flow rate in order to meet the requirement of oxidant for the electrochemical reaction. This can be achieved by changing the motor speed via a pulse width modulation control. The strategy of the cathode oxidant supply in different power conditions is summarized as follows:

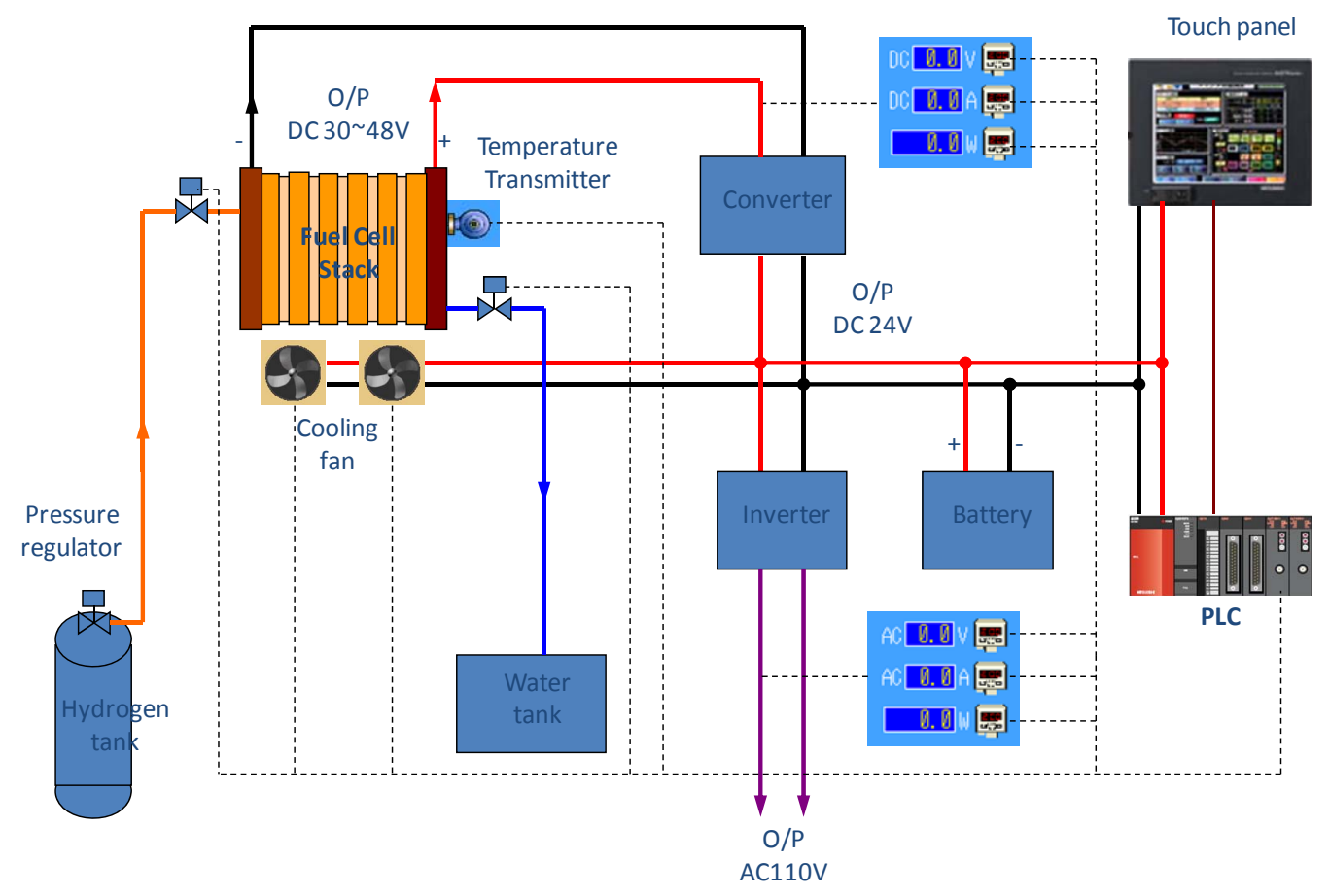

Figure 1. Functional block diagram of the fuel cell control system. 
Table 1. Characteristic data of fuel cell stack.

\begin{tabular}{cc}
\hline Specification & \\
\hline Number of cells & 60 \\
Nominal power (at 0.7V/cell) & $0.8 \mathrm{~kW}$ \\
Nominal voltage & $37 \mathrm{~V}$ \\
Nominal current & $27 \mathrm{~A}$ \\
Peak power (at 0.6V/cell) & $1.0 \mathrm{~kW}$ \\
Active area (cm ${ }^{2}$ ) & $100 \mathrm{~cm}^{2}$ \\
Operation conditions & \\
Anode (pure $\mathrm{H}_{2}$ ) & \\
Pressure & $150 \mathrm{kPa}$ \\
Temperature & $25^{\circ} \mathrm{C}$ \\
Relatively humidity & $100 \%$ \\
Cathode (Air) & \\
Pressure & \\
Temperature & 2.5 \\
Relatively humidity & Ambient pressure \\
Stoichiometric ratio & $25^{\circ} \mathrm{C}$ \\
\hline
\end{tabular}

1) At low power consumption, the air flow rate is kept at a constant level that supports the electrochemical reaction.

2) At high power consumption, the air flow varies in order to meet the manufacturer's recommended stoichiometric ratio larger than 2.5. As the power delivery by the fuel cell increases, the blower motor speed increases in order to provide more oxidant to the cathode side. This is because the stoichiometric ratio is less than 2.5. Conversely, the blower motor slows down as the fuel cell power is reduced. Such an action benefits the system efficiency through power saving.

3) As the fuel cell system starts or resets, the blower runs with full power in a short period of time in order to remove the water and/or inert gas inside the cathode.

In the above conditions, the stoichiometric ratio of the cathode oxidant is always larger than 2.5. The purpose of the high oxidant stoichiometric ratio is not only to supply enough oxygen to the cathode but also to remove the byproduct water from the cathode using a strong cathode stream $[10,11]$. Reactant humidification is critical to the performance of a PEM fuel cell stack, particularly in the cathode side and use replaceable fiber bipolar plate of fuel cell stack.

Controlling the PEM fuel cell operation requires a smart microcontroller together with the proper algorithm that can start monitor and shut down the fuel cell system safety under all possible operating conditions. As shown in Figure 2, easy-taken high capacity hydrogen barrel embedded into steel plate of this movable system and more convenient than other fuel cell system, the microcontroller is capable of monitoring the voltage, current, temperature, and pressure. It also takes appropriate actions in order to drive the external devices such as air blowers, solenoid valves, water pumps, and turbo-fans. A remote LCD display located on the board is interfaced with the microcontroller in order to monitor the output of the system. In addition, the voltage of each cell within the fuel cell stack is monitored by a 60-channel analog multiplexer in order to detect if the individual cell failures or not. Custom-built analog isolation amplifier circuits are used to isolate the microcontroller from the fuel cell stack's high voltage. When the emergency shutdown occurs, the microcontroller will store the current system parameters. These parameters can be read directly from the LCD display or downloaded to the personal computer through the RS232 communication port. The system supply two $110 \mathrm{v}$ plugs at each side of steel plate on this system. Therefore, in emergent situation, this high performance fuel cell stack with replaceable fiber bipolar plate movable fuel cell system can supply emergent power.

The PEM fuel cell main controller PLC module can receive multiple digital/analog input signals and then activate digital/analog output signals to control system components. By the way, the automation operation and real-time monitoring of fuel cell system can be done via programmable sequence control. The power transformation system mainly includes the DC/DC converter and DC/AC inverter. The small amount of voltage generated by battery pack is transformed to $24 \mathrm{~V}$ DC via DC/DC converter to provide the required power of control device

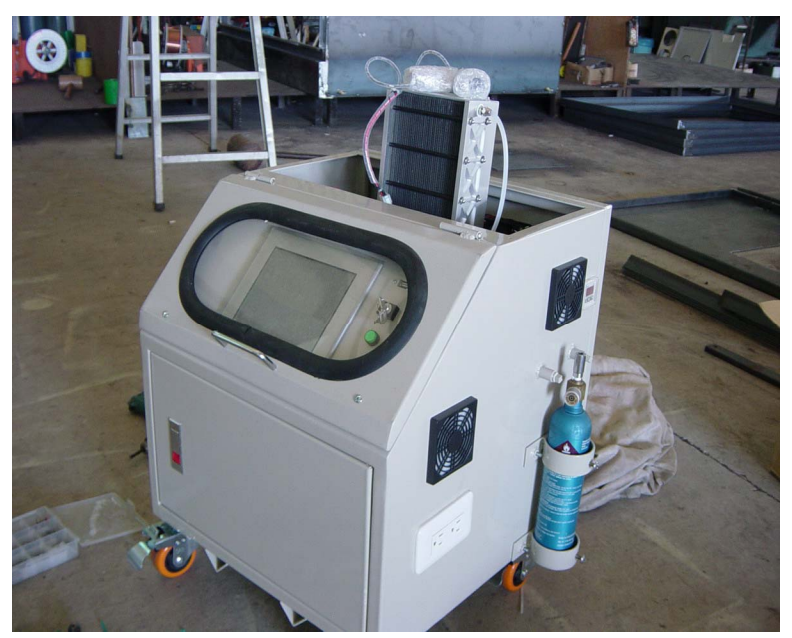

Figure 2. Integrated movable system of fuel cell. 
components. The most electrical power usage is through the DC/AC inverter to become $110 \mathrm{~V}$ AC $60 \mathrm{~Hz}$. The data acquisition system (DAS) includes the main touch screen and CF memory card. The PLC synchronization signal measurements are recorded and stored in the CF memory card. The data can be saved in the computer for further analyses.

\subsection{Power Supply}

The power conditioning system provides regulated DC or AC power appropriate for the application [12,13]. It is the major component of fuel cell system. The output of fuel cell power is an unregulated DC voltage and needs to be conditioned in order to be of practical use. The power conditioner section converts the raw power into useable power for different applications. The power conditioning unit also controls the frequency of electricity and maintains harmony to an acceptable current from fuel cell to suit the electrical needs of the application. The general configuration of the system will be the buck converter followed by a fuel cell stack and then processed by an inverter. The buck converter for the fuel cell will be operated in the voltage control mode. The block diagram of the power conditioner with the fuel cell control strategies incorporated is shown in Figure 3. There are two separate control loops for dc/dc converter control and the dc/ac inverter control. The unregulated output voltage (DC 30 - $48 \mathrm{~V}$ ) of fuel cell is fed to the dc/dc buck converter. Being unregulated, it has to be adjusted to a constant average value ( $36 \mathrm{~V}$ ) by adjusting the duty ratio to the required valve. The voltage is bucked depending upon the duty ratio. The duty ratio of the buck converter is adjusted with the help of a fuzzy logic controller from PLC link and touch panel.

\subsection{Power System and PLC Control Procedure}

Control process description of PLC control system is shown in Figure 4. When the power control system starts (for control power supply Power ON), fuel cells enter the start state. Right now, this system uses the temporary battery power to backup from control system. (Battery power supply DC24 V). Then control system first checks hydrogen and nitrogen gas supply pressure which only has a limited range. If something wrong happens in the system, the warning messages will activate from human-

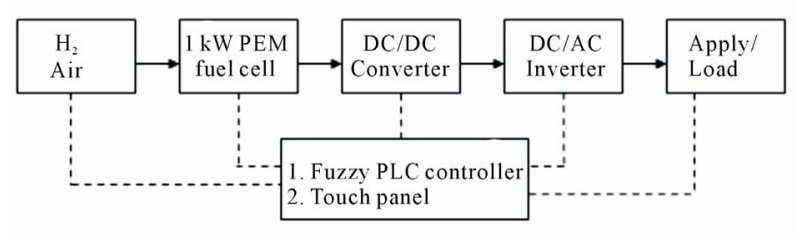

Figure 3. Intelligent fuel cell control system block diagram. machine interface of touch panel display

Be sure to avoid mixing hydrogen and air in the pipeline. Nitrogen gas must purge the pipeline beforehand to clear the remained hydrogen gas before operation. After nitrogen gas purging is finished, hydrogen and air begin to supply. At this moment, hydrogen and oxygen start to supply to the fuel cell stack and then power can be pull out. Control system continued to monitor the fuel cell output voltage and temperature. When the fuel cell load output voltage is above $48 \mathrm{~V}$, the system is ready to reach the normal start state (Standby). The power from the fuel cell stack will supply to battery system. In the mean time, the battery charges until it achieve full power status and then it automatically turns off.

\subsection{Operation Flow Chart}

When the voltage, current, and operating temperature setting value of fuel cells approaches the operating range, it is the normal operation of the system state. In the normal operation of the state it is divided into four parts and is described as shown in Figure 5

In the fuel cell standby condition, the power from fuel cell system can feed the required consumption of electric power in system. It also feeds AC load through the DC/AC inverter. Via the voltage converter, the fuel cell output voltage converts from DC $30-48 \mathrm{~V}$ to DC $24 \mathrm{~V}$. After 1 second, it starts to convert DC $24 \mathrm{~V}$ into AC 110 $\mathrm{V}(60 \mathrm{~Hz})$. If the load control rely is normal, the AC 110 $\mathrm{V}$ electricity will supply to the household appliance. If it detects an inverter problem after 5 seconds, a warning message from the Human-Machine Interface will inform the operator and also record the message.

The amount of air flow varies with the load and fuel cell operation temperature. Without the extra load, the air flow keeps $45 \%$ of the output supply in order to maintain the operation of fuel cell stack. When the load increases, the output current also increases and the air flow increases for the output need

The fuel cell's vent valve can automatically adjust the purge time to follow the different output power. From a $1 \mathrm{~kW}$ fuel cell, the purge time can be set as

$\mathrm{L}: 0 \mathrm{~W} \leqq$ output power $<300 \mathrm{~W}$ Purge OFF $20 \mathrm{sec}-$ ond, Purge ON 0.3 second

M: $300 \mathrm{~W} \leqq$ output power $<600 \mathrm{~W}$ Purge OFF 15 second, Purge ON 0.4 second

$\mathrm{H}: 600 \mathrm{~W} \leqq$ output power $<1000 \mathrm{~W}$ Purge OFF 10 second, Purge ON 0.5 second

In the water and heat transfer management, the cooling water circulation system can maintain the temperature of the fuel cell in operation condition. When the fuel cell's temperature is higher than the preset operating temperature, cooling fans pump starts to power on to cool the system. When the water temperature is too high, the sys- 


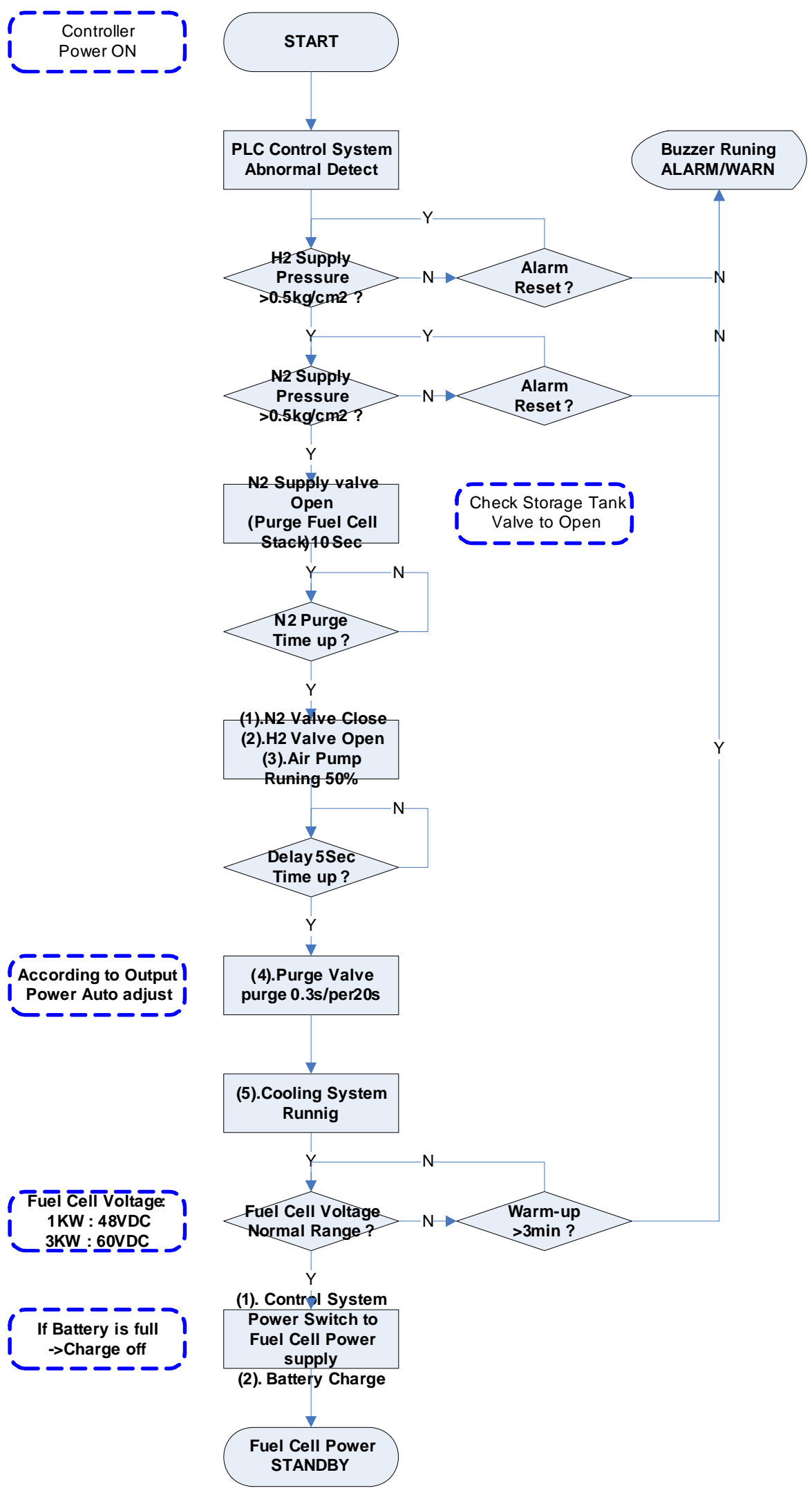

Figure 4. Flow chart diagram of PLC control system. 


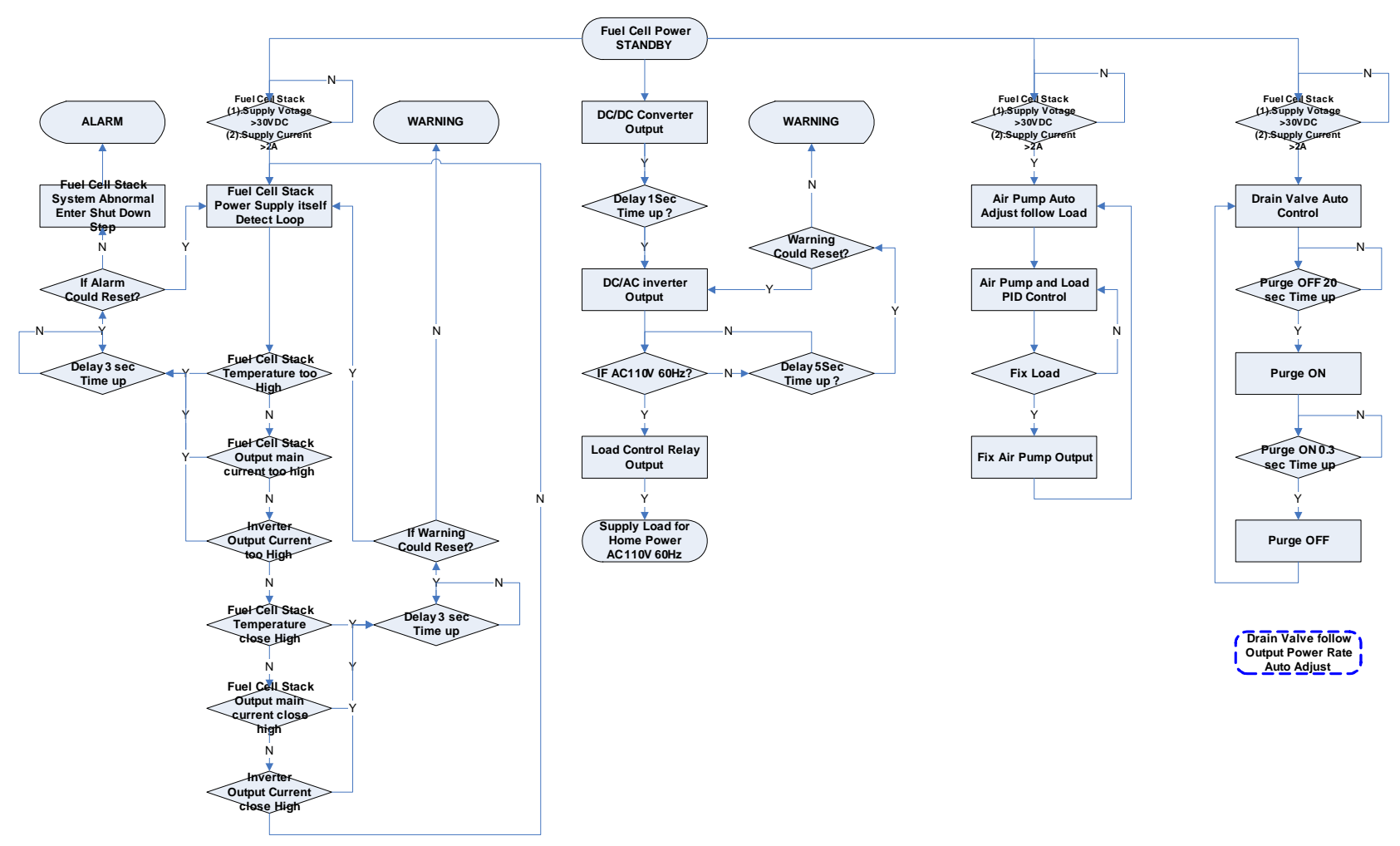

Figure 5. The normal operation of the state flow chart.

tem self-switched fan starts to emit more of the heat and maintain the fuel cell operating temperatures in the proper range. The cooling fan speed will change with the temperature measurements that the higher the temperature it is, the faster the fan speed needs to cool the system.

\subsection{Control Circuit Design}

$\mathrm{n}$ order to replace the traditional-style control interface, reducing costs and increasing flexibility and production management, computers, controllers and PLC devices via a standard communication interface between the multiconnect should be arranged appropriately, as shown in Figures 6 and 7. The controller can do the communication between people and machine friendly. It establishes a friendlier human-machine interface. Graphical monitoring control system is shown in Figure 8. Department of monitoring the computer graphical user interface through a communication interface, through on-site controller, on-site equipment, the operation or set the parameters were issued by the command. Meanwhile, it will be onsite equipment operation status and operation information for graphic display on the monitor of the computer screen. The operator is operating on-site equipment to clear the situation, and adequately operate the machine in order to enhance the production availability factor.

\section{Results and Discussions}

Smart Movable Fuel Cell Control System for HumanMachine Interface Planning and Function The color of switching solenoid valve on Human-machine interface (Touch Panel) represents the status of system. The green color means open and red means close. It includes the inspection of hydrogen and air inlet pressure. $1 \mathrm{~kW}$ fuel cell system consists of three motor-driven components (air compressor, cooling water circulation pump, and cooling fan). The operator can stimulate the motor operation via inputting 4 - $20 \mathrm{~mA}$ values. As system startup, the human-machine interface starts to operate on an automated system to start power generation. The explanation of the Human-Machine Interface screen. The temperature of the fuel cell can be measured with k-type thermocouple. It shows the overall fuel cell voltage, DC current, and power. It also shows the overall output AC voltage, AC current, frequency, and power.

The material of bipolar plate is PA6\TECHNYL C218 V40\Rhodia (with 40\% fiber). The melt front is shown in Figures 9(a) and (b). It is shown that the melt front of bipolar front without fiber caused melding line at the end of filling and not supporting permanent performance. In the other hand, melt front of bipolar plate with fiber has better filling and gets more strength because of high per 


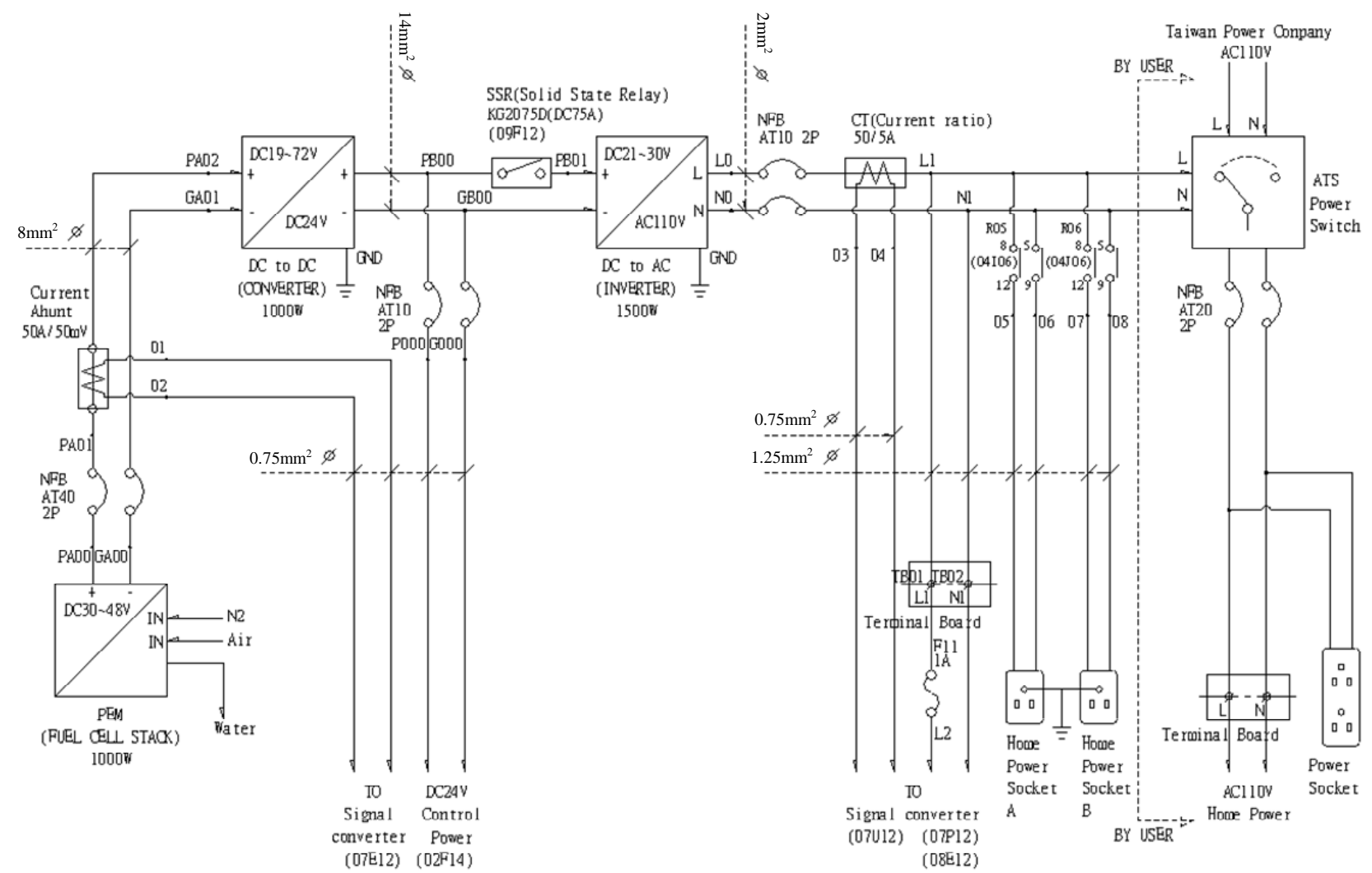

Figure 6. Circuit diagram of fuel cell dynamic power supply system.

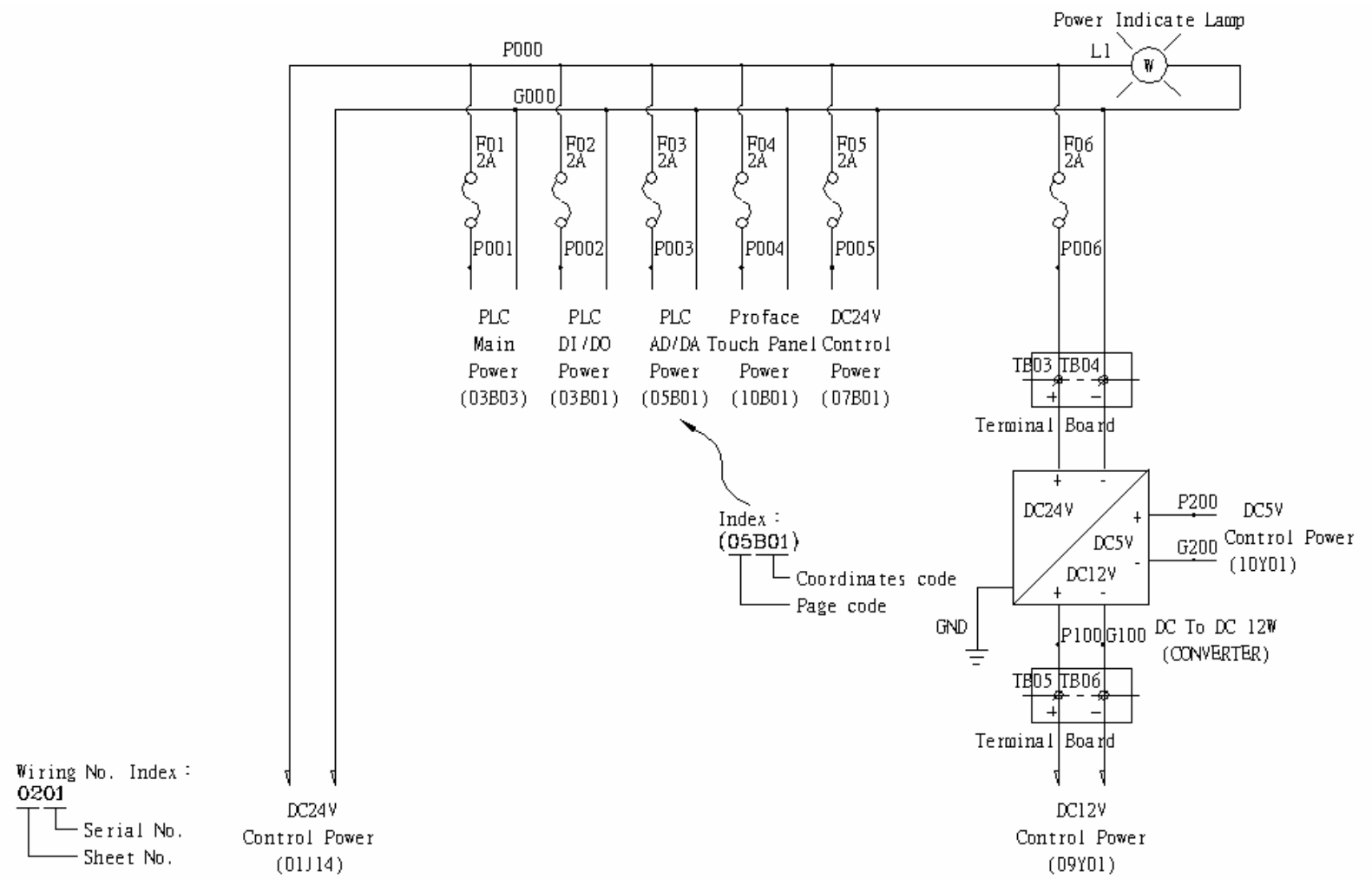

Figure 7. Circuit diagram of fuel cell control system. 

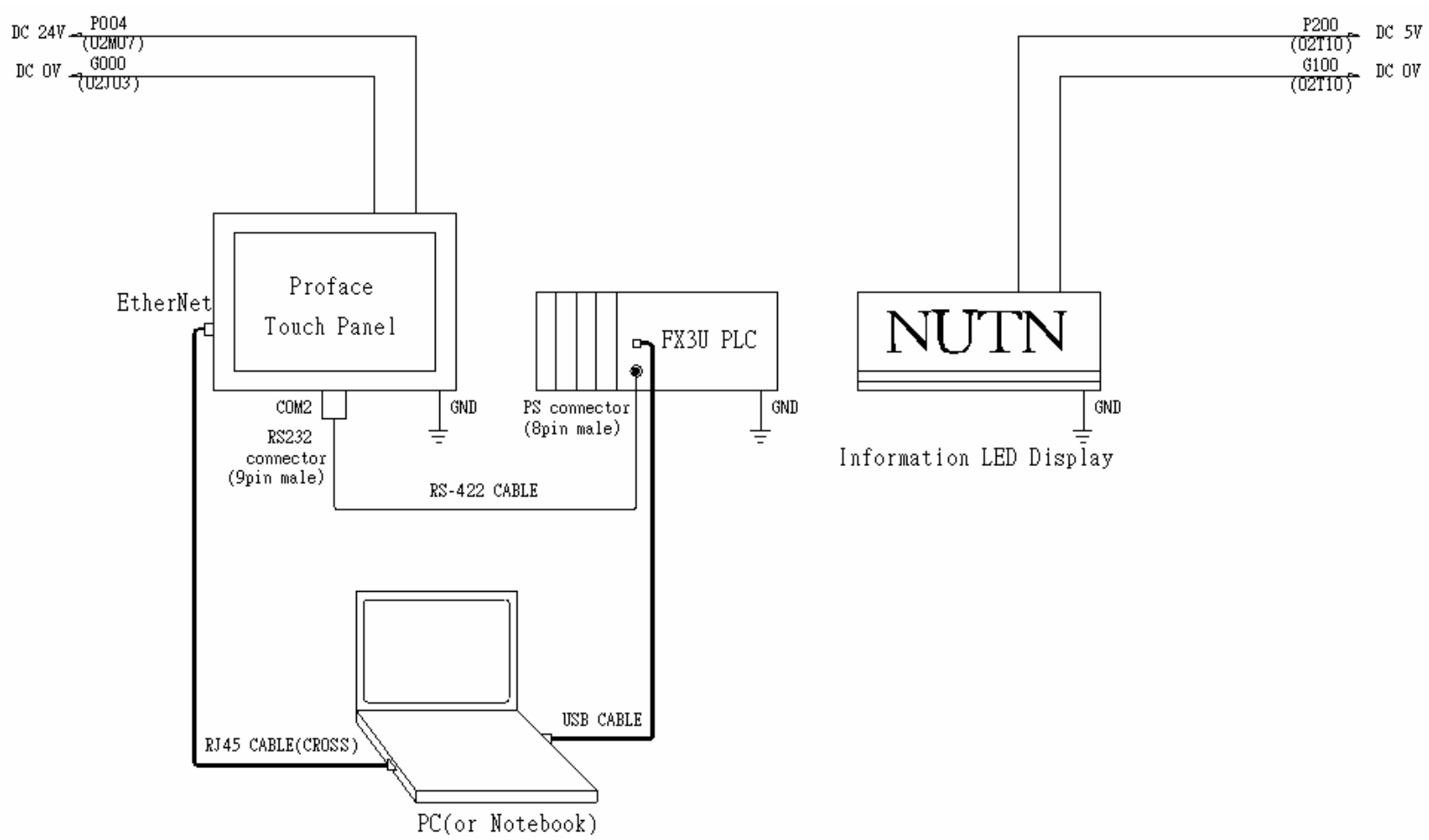

Figure 8. Graphical user interface control system.

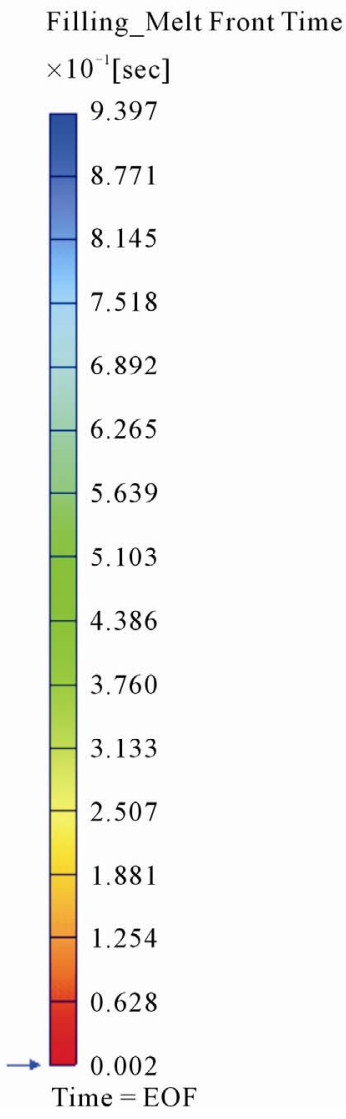

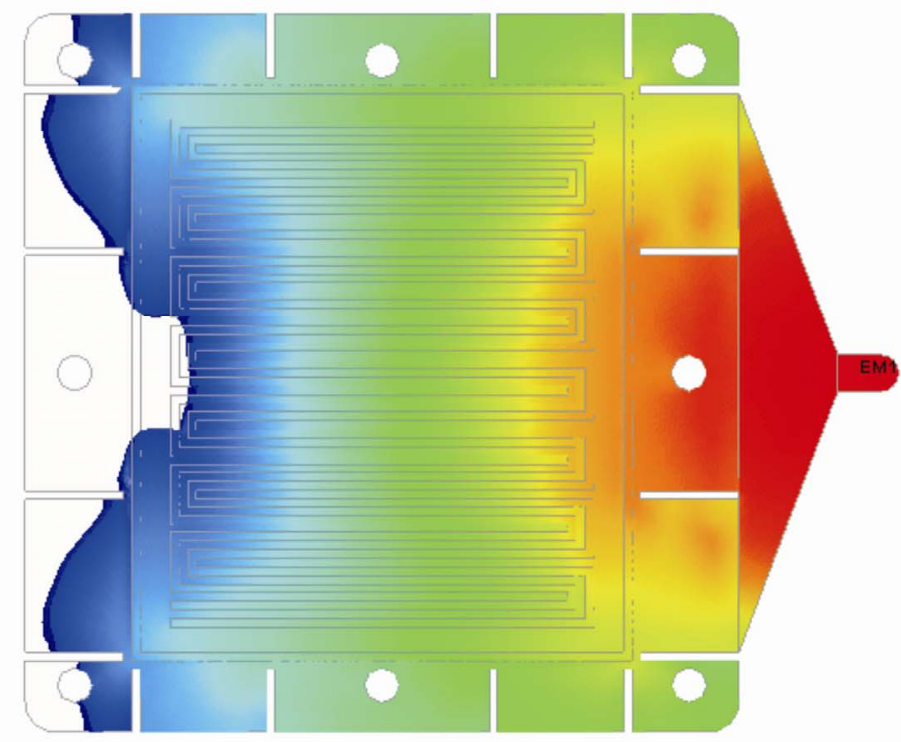

(a) 
Moldex3D

Filling_Melt Front Time
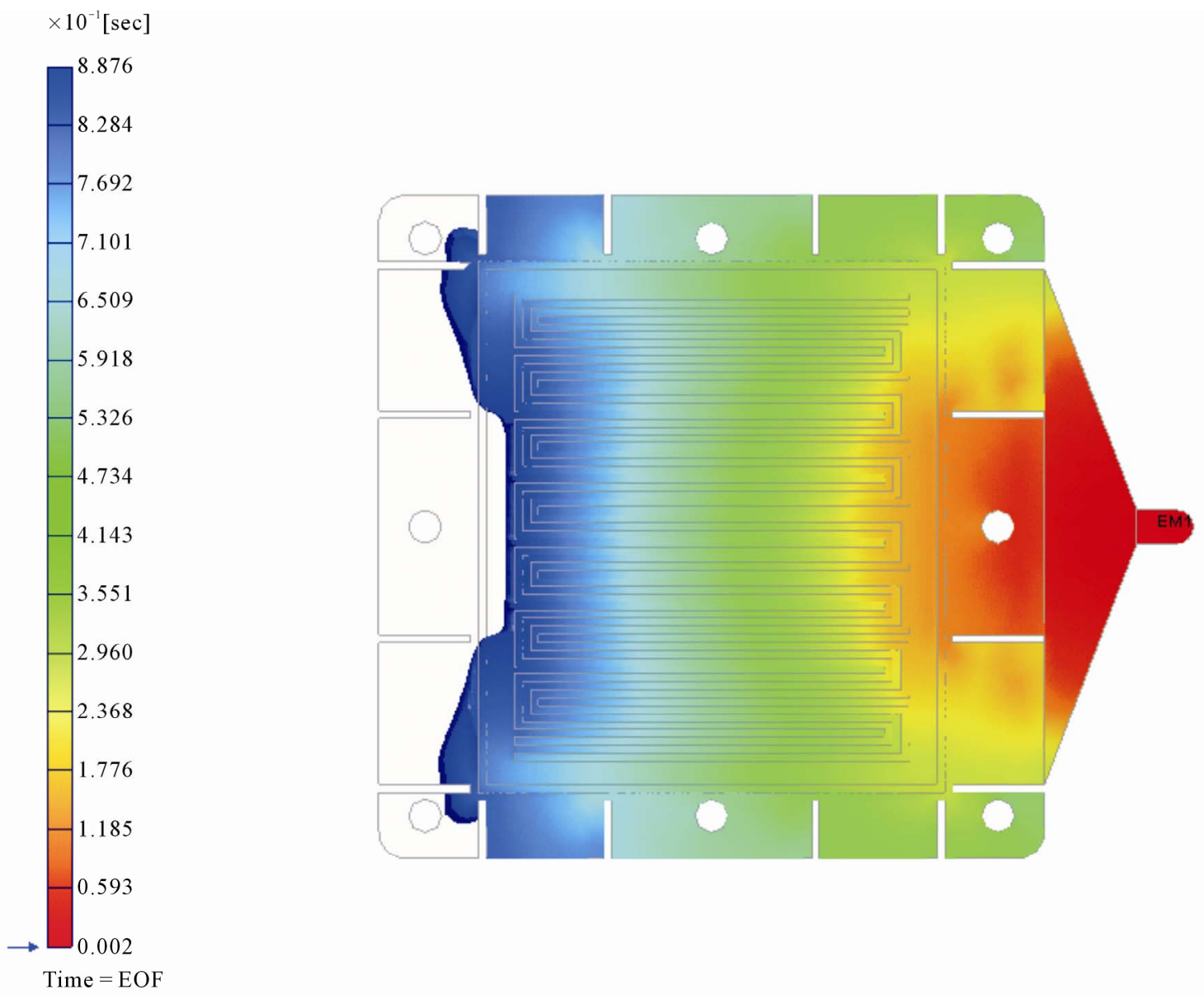

(b)

Figure 9. Melt front of bipolar plate for injection molding process. (a)Without Fiber; (b) With Fiber.

centage fiber orientation shown in Figure 10. Therefore, the movable fuel cell system has chosen replaceable fiber bipolar plate of fuel cell stack.

The stack consists of 60 cells with an active area of $100 \mathrm{~cm}^{2}$. The nominal and peak powers are $0.8 \mathrm{~kW}(0.7$ $\mathrm{V})$ and $1.0 \mathrm{~kW}(0.6 \mathrm{~V})$ respectively. The polarization curve shown in Figure 11 is determined via a commercial test stand that can easily provide optimal operation control condition for the stack. The electric power supplied to the components from the fuel cell stack should be regulated in voltages $(24 \mathrm{~V})$ using dc/dc buck converters. Therefore, the PEM fuel cell output voltage can be operated safely in the linear range of voltage form 24 $\mathrm{V}$ for power supply.

\section{Conclusions}

Computers, controllers, and PLC devices were via a stan- dard communication interface between the multi-connect. This system also has the properties of high stability and easy expansion characteristics. The controller can achieve the communication convenience on human-machine interface. The results of this study are to establish the novel PEM fuel cell stack control system and use replaceable fiber polar plate fuel cell stack. The system is able to real-time monitor the variation of fuel cell performance during operation and record all of the conditions and parameters from integrated human-machine interface. In order to replace the traditional-style control interface, costs are reduced and flexibility and production management are increased. In order to monitor the site, on-site data and images with vivid color changes through the terminal display can be obtained through the communication interface and controller status to achieve the purpose of monitoring the site. Thus, in the database and 

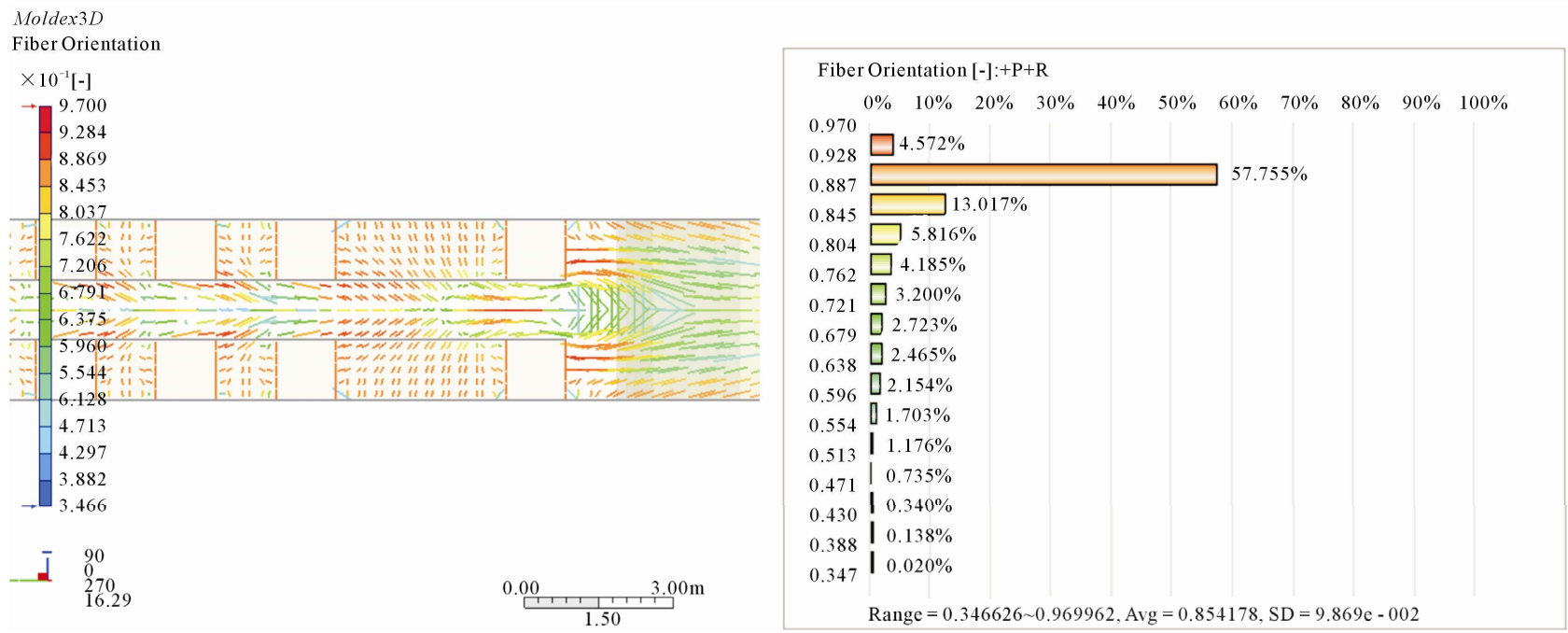

Figure 10. Fiber orientation of bipolar plate.

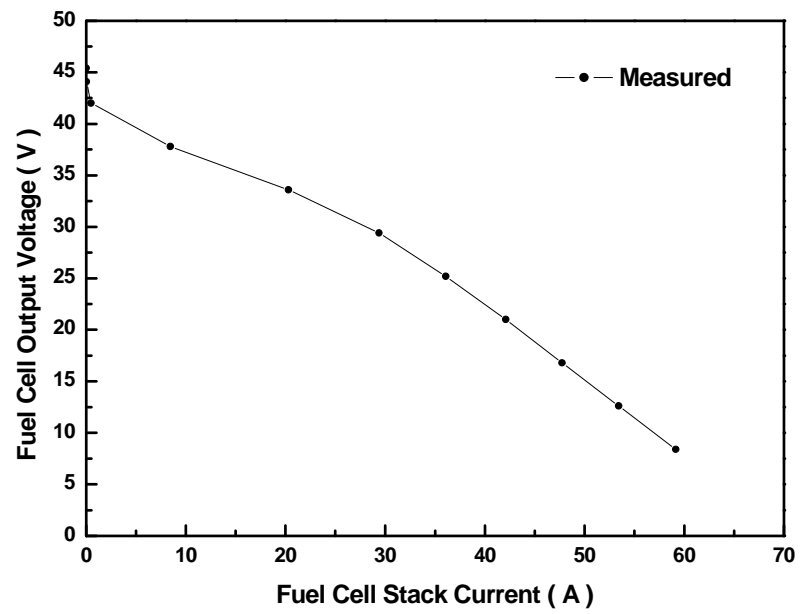

(a)

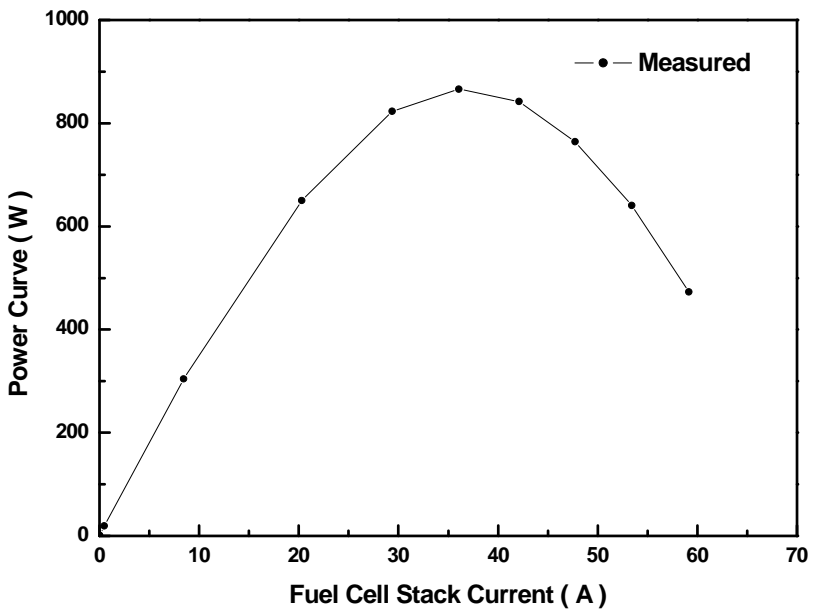

(b)

Figure 11. Polarization curve of the PEMFC stack. (a) Fuel cell output voltage; (b) Power curve.

graphics defined in the on-site conditions and the occurrence of conditions, in order to perform specific actions, it is necessary to retain flexibility of automatic and manual controls. Moreover, this system use easy-taken high capacity hydrogen barrel embedded into steel plate of this movable system and more convenient than other fuel cell system and supply emergent power for two $110 \mathrm{~V}$ plugs of each side of steel plate of this system. Therefore, the research and development results present high convenient and movable integrated fuel cell power supply system.

\section{REFERENCES}

[1] J. O. Schumacher, P. Gemmar, M. Denne, M. Zedda and M. Stueber, "Control of Miniature Proton Exchange Membrane Fuel Cells Based on Fuzzy Logic,” Journal of
Power Sources, Vol. 129, No. 2, 2004, pp. 143-151. doi:10.1016/j.jpowsour.2003.10.010

[2] J. M. Correa, F. A. Ferret, L. N. Canha and M. G. Simoes, "An Electrochemical Based Fuel Cell Model Suitable for Electrical Engineering Automation Approach,” IEEE Trans Industrial Electron, Vol. 51, No. 5, 2004, pp. 11031112. doi:10.1109/TIE.2004.834972

[3] S. Pasricha, M. Keppler, S. R. Shaw and N. M. Hashem, "Comparison and Identification of Static Electrical Terminal Fuel Cell Models,” IEEE Trans Energy Conversion, Vol. 22, No. 3, 2007, pp. 746-54. doi:10.1109/TEC.2007.895465

[4] A. J. del Real, A. Arce and C. Bordons, "Development and Experimental Validation of a PEM Fuel Cell Dynamic Model,” Journal of Power Sources, Vol. 173, No. 1, 2007, pp. 310-324. doi:10.1016/j.jpowsour.2007.04.066 
[5] A. Kirubakaran, S. Jain and R. K. Nema, "A Review on Fuel Cell Technologies and Power Electronic Interface,” Renewable and Sustainable Energy Reviews, Vol. 13, No. 9, 2009, pp. 2430-2440. doi:10.1016/j.rser.2009.04.004

[6] R. Tirnovan, A. Miraoui, R. Munteanu, I. Vadan and H. Balan, "Polymer Electrolyte Fuel Cell System (PEFC) Performance Analysis,” IEEE International Conference Automation, Quality and Testing Robotics, Cluj-Napoca, 25-28 May 2006, pp. 457-462. doi:10.1109/AQTR.2006.254580

[7] D. K. Choi, B. K. Lee, S. W. Choi, C. Y. Won and D. W. Yoo, "A Novel Power Conversion Circuit for Cost-Effective Battery-Fuel Cell Hybrid Systems," Journal of Power Sources, Vol. 152, No. 1, 2007, pp. 245-255. doi:10.1016/j.jpowsour.2005.01.050

[8] J. K. Kuo and C. K. Chen, "The Effects of Buoyancy on the Performance of a PEM Fuel Cell with a Wave-Like Gas Flow Channel Design by Numerical Investigation,” International Journal of Heat and Mass Transfer, Vol. 50, No. 21-22, 2007, pp. 4166-4179. doi:10.1016/j.ijheatmasstransfer.2007.02.039

[9] J. K. Kuo and C. K. Chen, "Improvement of the Per- formance of the Gas Flow Channel in the PEM Fuel Cells,” Energy Conversion and Management, Vol. 49, No. 10, 2008, pp. 2776-2787. doi:10.1016/j.enconman.2008.03.024

[10] S. Y. Choe, J. G. Lee, J. W. Ahn and S. H. Baek, "Integrated Modeling and Control of PEM Fuel Cell Power System with a PWM DC/DC Converter," Journal of Power Sources, Vol. 164, No. 2, 2007, pp. 614-623. doi:10.1016/j.jpowsour.2006.10.082

[11] J. J. Hwang, D. Y. Wang and N. C. Shin, "Development of a Lightweight Fuel Cell Vehicle,” Journal of Power Sources, Vol. 141, No. 1, 2005, pp. 108-115. doi:10.1016/j.jpowsour.2004.08.056

[12] A. Sakhare, A. Davari and A. Feliachi, "Fuzzy Logic Control of Fuel Cell for Stand-Alone and Grid Connection,” Journal of Power Sources, Vol. 135, No. 1-2, 2004, pp. 165-176. doi:10.1016/j.jpowsour.2004.04.013

[13] C. L. Chang, C. Y. Chen, C. C. Sung and D. H. Liou, "Fuel Sensor-Less Control of a Liquid Feed Fuel Cell under Dynamic Loading Conditions for Portable Power Sources (I),” Journal of Power Sources, Vol. 182, No. 1, 2008, pp. 133-140. doi:10.1016/j.jpowsour.2008.04.026 